\title{
Effects of orange by-product fiber incorporation on the functional and technological properties of pasta
}

\author{
Tainara de Moraes CRIZEL ${ }^{1}$, Alessandro de Oliveira RIOS ${ }^{1}$, Roberta Cruz Silveira THYS ${ }^{1}$, Simone Hickmann FLÔRES ${ }^{1 *}$
}

\begin{abstract}
The incorporation of fiber into products consumed every day by the general population is important and viable. The aim of the present work was to evaluate the impact of incorporating orange juice industry dietary fiber byproducts in fettuccini of fresh pasta. Three different fiber concentrations were added to fresh pastas $(25 \mathrm{~g} / \mathrm{kg}, 50 \mathrm{~g} / \mathrm{kg}$ and $75 \mathrm{~g} / \mathrm{kg})$. The results showed a significant increase in solid loss content when the incorporation of orange fiber was greater than $50 \mathrm{~g} / \mathrm{kg}$. This difference did not occur regarding weight increase values and color parameters. The pasta with $75 \mathrm{~g} / \mathrm{kg}$ orange fiber can be considered a "high fiber" product, with the total dietary fiber content of the pasta increasing by $99 \%$ compared to control pasta. The carotenoid and phenolic contents of pasta increased significantly with the incorporation of fiber at $75 \mathrm{~g} / \mathrm{kg}$, but only the pasta formulation with $25 \mathrm{~g} / \mathrm{kg}$ of orange fiber did not differ from control pasta in relation to all of the sensory attributes and presented an acceptance greater than $75 \%$. The addition of orange fiber byproducts to pastas is an interesting alternative because fiber has a high nutritional value and an abundance of antioxidants.
\end{abstract}

Keywords: orange fibre; fresh pasta; by-products; sensory acceptance.

Practical Application: Orange juice industry byproduct fiber in fresh pasta improves the functional quality.

\section{Introduction}

Recently, more attention has been dedicated to the utilization of fruit processing byproducts. Such use contributes to a better utilization of available resources and results in the production of various new ingredients containing dietary fiber (O'Shea et al., 2012; Lima et al., 2014). The use of byproducts is of interest due to functional, technological and nutritional properties, as well as health benefits, reduced risks of industrial environmental contamination and lower costs (Schieber et al., 2001).

An important and potential source of dietary fiber are orange juice industrial byproducts because this material is available in large quantities, has a low cost and has associated bioactive compounds (Romero-Lopez et al., 2011; Grigelmo-Miguel \& Martin-Belloso, 1999). All of these factors make the use of dietary fiber byproducts in different products interesting and viable.

The fiber obtained from orange juice byproducts can be used as an ingredient in the food industry, mainly for its nutritional and functional characteristics. Orange fibers have a high content of total dietary fiber and are a good source of bioactive compounds such as phenolics and carotenoids (Crizel et al., 2013).

The incorporation of fiber into wheat flour in products consumed every day by the general population is important and viable. Among these products, pasta stands out due to a generally good acceptance and worldwide consumption due to low cost, manufacturing ease, versatility, sensory attributes and long shelf life (Bergman et al., 1994). According to Abima (Brazilian Association of Manufacturers of Pasta), fresh pasta consumption rose by $84 \%$ between 2008 and 2012 (Associação Brasileira das Indústrias de Massas Alimentícias Pão \& Bolo, 2014).

Some studies have indicated the possibility of adding dietary fiber fruit byproducts to wheat flour in pasta preparations, but the results remain controversial due to these additions influencing the organoleptic properties of pasta. Ajila et al. (2010) evaluated the incorporation of mango peel powder to macaroni and found that it resulted in an increase in the content of polyphenols, carotenoids and dietary fiber. The pasta with $50 \mathrm{~g} / \mathrm{kg}$ fiber had a good acceptability by the panelists, although there has been an increase of solid loss during the cooking. The incorporation of grape marc powder in fettuccini pasta increased the total phenolic content, condensed tannins, anthocyanin and antioxidant compounds. However, the incorporation of grape powder caused a decrease in the acceptance of the aroma, aftertaste, flavor and appearance in the sensory analysis (Sant'Anna et al., 2014).

The objective of the present work is to evaluate the impact of incorporating orange juice industry byproducts dietary fiber in fettuccini fresh pastas. The pastas were evaluated in relation to their nutritional, cooking and sensory properties.

\section{Materials and methods}

\subsection{Orange fiber}

The orange fiber was prepared from byproducts from the orange juice industry such as peel, pulp (flavedo and albedo), and seeds. The fresh material was provided by "Pure Juice", a 
company located in Porto Alegre (RS/Brazil). The orange fiber was prepared according to the methodology by Crizel et al. (2013). The residues were dried in oven with forced air circulation (DeLeo, Model B5AFD, Brazil) at $55^{\circ} \mathrm{C}$ for 24 hours. The milled fiber was separated using sieves for particle size analysis (Bertel, Brazil); the separated particles were smaller than $125 \mathrm{~mm}$ (mesh 115).

\subsection{Pasta preparation}

The fresh pasta was prepared with wheat flour (Triticum aestivum, $12 \mathrm{~g} / \mathrm{kg}$ moisture, $98 \mathrm{~g} / \mathrm{kg}$ protein) (Orquídea, Moinho Tondo, Brazil), filtered water and different concentrations of orange dietary fiber. Fettuccini pastas (FP) were coded FP0, FP25, FP50, and FP75 according to the percentage of orange byproduct dietary fiber incorporation: $0 \mathrm{~g} / \mathrm{kg}, 25 \mathrm{~g} / \mathrm{kg}, 50 \mathrm{~g} / \mathrm{kg}$ and $75 \mathrm{~g} / \mathrm{kg}$, respectively. In each formulation, the wheat flour, orange fiber and water $(300 \mathrm{~g} / \mathrm{kg})$ were mixed in an industrial mixing machine (G. Paniz, Mod 90334, Brazil) for 15 minutes. Afterwards, the dough was extruded (G. Paniz, Mod 90334, Brazil) through a die to obtain the fettuccini shape (0.5- $\mathrm{cm}$ wide and $2-\mathrm{mm}$ thick) and the product was manually cut into $20-\mathrm{cm}$ pieces.

\subsection{Proximate composition}

The pasta proximate analyses were performed according to the Association of Official Analytical Chemist (1990). The moisture content was determined at $105{ }^{\circ} \mathrm{C}$ (DeLeo, model 48 TLK, Brazil). The total protein content (\% $\mathrm{N}$ x 5.7) was determined by the Kjeldahl method. The lipid content was determined using a Soxhlet extractor (Foss Soxtec, model $2055^{\mathrm{TM}}$, Denmark). The ash content was performed in a muffle furnace (Elektro Therm Linn, 312.6 SO LM 1729, Germany) set to $550{ }^{\circ} \mathrm{C}$. The carbohydrate content was determined by the difference from the above measurements. The results are expressed as grams per $100 \mathrm{~g}$ of dry matter (DM). All analyses were performed in triplicate.

\subsection{Dietary fiber composition}

The total dietary fiber, both soluble and insoluble, was determined by the enzyme-gravimetric method described by the Association of Official Analytical Chemist (1990), method 991.43.

\subsection{Pasta quality}

Pasta cooking quality

Optimum cooking time (OCT), solid loss and cooked weight methodology were determined according to the American Association of Cereal Chemists Official Methods 16-50 and 16-51 (American Association of Cereal Chemists, 2000). Pasta $(10 \mathrm{~g})$ was broken into $5-\mathrm{cm}$ pieces and cooked in boiling distilled water $(170 \mathrm{ml})$. Boiling was maintained during the cooking period. The time when the inner white core of the pasta disappeared was identified as the OCT (al dente point). After cooking, the pasta was drained for $1 \mathrm{~min}$ to expel the residual water. An aliquot of $10 \mathrm{ml}$ of cooking water was put into a metal capsule and dried at $105^{\circ} \mathrm{C}$ (DeLeo, model 48 TLK, Brazil) until constant weight to evaluate the presence of solids from the pasta. The solid loss was expressed as a percentage of the raw pasta. At this stage, pasta samples were weighed to determine the cooked weight and the percentage of weight increase. All tests were performed in triplicate.

\section{Total phenolic compounds}

The determination of total phenolic compounds present in control pasta and orange fiber-incorporated pasta (cooked and uncooked) was performed by the spectrophotometric method of Folin and Ciocalteu (Singleton \& Rossi, 1965) using gallic acid as a standard. The absorbance was measured at $725 \mathrm{~nm}$, and the results are expressed as milligrams of gallic acid equivalents (GAE) per gram of dry sample $(\mathrm{mg} / \mathrm{g})$. To extract the total phenolic compounds, $3.0 \mathrm{~g}$ of sample was homogenized with $10 \mathrm{~mL}$ of a methanol:water $(80: 20 \mathrm{v} / \mathrm{v})$ solution acidified with $1 \% \mathrm{HCl}$ in an Ultra-Turrax homogenizer (IKA, Ultra-Turrax_ T25 digital, Germany) for $2 \mathrm{~min}$. The extract was then allowed to stand for 1 hour and was centrifuged $(25000 \times \mathrm{g}$ for $20 \mathrm{~min}$, Hitachi, model CR216III, Japan) at $4{ }^{\circ} \mathrm{C}$.

\section{Total carotenoids}

Pasta samples (cooked and uncooked) ( $3 \mathrm{~g}$ ) were homogenized with $10 \mathrm{~mL}$ of ethanol in an Ultra-Turrax homogenizer (IKA, Ultra-Turrax_ T25 digital, Germany) for 2 min to extract the carotenoids. The extract was allowed to stand for 1 hour and was then centrifuged $(25000 \times \mathrm{g}$ for $20 \mathrm{~min}$, Hitachi, model CR216III, Japan) at $4{ }^{\circ} \mathrm{C}$. The total carotenoid content was estimated according to the method described by Lichtenthaler (1987) using the carotenoid found in the highest amount in the orange fiber by Crizel et al. (2013), the lutein (Absorption coefficient: 2550), and employing the Equation 1 below. The absorbance was measured at $445 \mathrm{~nm}$ using a spectrophotometer, and the total carotenoids obtained from equation are expressed as micrograms per gram of dry sample.

$$
x(\mu g)=\frac{A B S \times Y(m L) \times 10^{6}}{2550 \times 100}
$$

\subsection{Color evaluation}

The color of uncooked and cooked pasta was assessed with a colorimeter (Minolta ${ }^{\circ}, \mathrm{CR} 400$, Japan) following the color system of CIE- $L^{*} \mathrm{a}^{*} \mathrm{~b}^{*}$, where the $L^{*}$ value (brightness) ranges from black (0) to white (100), the chroma $a^{\star}$ value ranges from green $(-60)$ to red $(+60)$, and the chroma $b^{*}$ value ranges from blue $(-60)$ to yellow (+60) (Minolta, 1993). The results are stated as the color differential $(\Delta \mathrm{E})$ between uncooked and cooked pasta and are calculated as follows Equation 2:

$$
\Delta E=\sqrt{\Delta L^{2}+\Delta a^{2}+\Delta b^{2}}
$$

where $\Delta \mathrm{L}$ is calculated as $L^{*}$ uncooked sample minus $L^{*}$ cooked sample; $\Delta a$ is calculated as $a^{*}$ uncooked sample minus $a^{*}$ cooked sample, and $\Delta b$ is calculated as $b^{*}$ uncooked sample minus $b^{*}$ cooked sample. The results are the mean of three determinations.

\subsection{Sensory analysis}

Samples of fresh pasta were sensory evaluated by the acceptance test. Each analysis was performed by 50 untrained members between 15 and 60 years old. The samples were 
cooked and served on disposable plates with approximately $30 \mathrm{~g}$ of each sample coded with a three digit random numbers. Acceptance attributes such as appearance, color, texture, flavor, aftertaste and overall acceptability were evaluated using a 9-point hedonic scale (Meilgaard et al., 2007). The pastas were served with commercial red sauce. The sensory evaluation of samples was performed on different days. The study was approved by the Ethics Committee of the University (Protocol No: 21912), and participants were informed of all of the details of the study. To calculate the percentage of acceptance of each attribute, Equation 3 was used (Dutcosky, 1996).

$$
\% \text { Acceptance }=\frac{\text { Average acceptance }}{9} \times 100
$$

\subsection{Statistical analysis}

The results were evaluated by analysis of variance (ANOVA) and Tukey's tests at a significance level of 0.05 using the software Statistica 11.0. (STATSOFT Inc.).

\section{Results and discussion}

The chemical composition of pasta with orange dietary fiber byproduct incorporation and control pasta is presented in Table 1 . As can be observed, there were no statistically significant $(p>0.05)$ differences in moisture, protein, lipid and carbohydrate content.

The ash content increased in FP50 and FP75. However, these samples did not differ from each other.

For all pasta samples, the optimum cooking time was approximately $4 \mathrm{~min}$, and the other cooking characteristics (solid loss and percentage weight increase) were estimated at this standard cooking time.

The cooking properties are an important parameter for the evaluation of pasta. Table 2 shows the cooking quality characteristics of control pasta (FP0) and orange fiber byproduct-enriched pastas (FP25, FP50 and FP75). As can be observed, FP25 was not significantly different compared to control pasta in solid loss. However, the solid loss significantly increased when the incorporation of orange fiber was $50 \mathrm{~g} / \mathrm{kg}$ and $75 \mathrm{~g} / \mathrm{kg}$, but these pastas are considered to be of good quality because the cooking loss was smaller than $12 \%$ for all levels of addition (Hoseney, 1999).

Similar results were obtained in a study by Ajila et al. (2010) who found that the incorporation of $50 \mathrm{~g} / \mathrm{kg}$ and $75 \mathrm{~g} / \mathrm{kg}$ of mango peel powder in dried macaroni also resulted in increased cooking loss ( $8.24 \%$ and $8.71 \%$, respectively). The similarity between the study results may be associated with structural changes in the protein network caused by plant-derived dietary fiber addition (orange and mango) (Torres et al., 2007).

Studies reveal that the use of higher temperatures in the drying step of pasta fabrication results in lower cooking losses (Granito et al., 2003). In the present study, fresh pasta was produced without a drying stage, and even so, the solid losses were lower than the results presented by Ajila et al. (2010) for semolina dried pasta. Thus, it can be verified that even without the use of semolina and the drying step, the pasta can be produced with sufficient quality.

Tudorica et al. (2002) reported that the increase in cooking loss could be due to the irregular distribution of water within the pasta matrix by the competitive hydration tendency of the fiber and due to an interruption of the protein-starch matrix.

Pasta samples showed no significant difference in increased weight values, indicating that the orange dietary fiber incorporation did not change the product quality.

There was a significant increase in the total dietary fiber (TDF) content in pasta supplemented with orange dietary fiber byproducts (Table 3). According to Brazilian normative $\mathrm{n}^{\circ} 27$ 13/01/1998 (Brasil, 1998), foods can be considered as a source of fiber if the products have at least $3 \mathrm{~g}$ of fiber/100 $\mathrm{g}$ sample, and foods with a "high fiber" content have $6 \mathrm{~g} / 100 \mathrm{~g}$ sample. Therefore, the pasta with $75 \mathrm{~g} / \mathrm{kg}$ orange fiber can be considered a "high fiber" product. TDF increased from 3.77\% (FP0) to $7.5 \%$ (FP75), an increase of $99 \%$. The insoluble dietary fiber (IDF) content increased from 1.58\% (FP0) to 4.36\% (FP75).

Padalino et al. (2014) developed a spaghetti enriched with pea flour and reported that the addition of $150 \mathrm{~g} / \mathrm{kg}$ pea flour contributed to a significant increase in the total dietary fiber (7.50\%) compared to the control sample (4.55\%), representing an increase of $65 \%$ in fiber content. The added $150 \mathrm{~g} / \mathrm{kg}$ of chickpea flour in pasta increased the total dietary fiber content by $48 \%$ in relation to a control pasta sample containing only semolina (Fares \& Menga, 2012). This difference in the increase in the total dietary fiber content of pastas is related to the chemical nature of the fiber added. Many studies show that some fruit byproducts are superior sources of dietary fibers compared to vegetables and cereals (Elleuch et al., 2011).

The total content of carotenoids in pastas increased significantly with the addition of $50 \mathrm{~g} / \mathrm{kg}$ and $75 \mathrm{~g} / \mathrm{kg}$ of orange byproducts dietary fiber. However, there was a significant decrease in the carotenoid content after cooking. Lutein is the carotenoid with

Table 1. Proximate analysis of uncooked control and orange fiber-enriched pasta.

\begin{tabular}{cccccc}
\hline Sample $^{1}$ & Moisture $(\%)^{2}$ & Protein $(\%)^{2}$ & ${\text { Lipids }(\%)^{2}}^{\left.\text {Ash }^{2} \%\right)^{2}}$ & ${\text { Carbohydrates }(\%)^{2,3}}^{\mathrm{a}}$ \\
\hline FP0 & $27.53 \pm 0.29^{\mathrm{a}}$ & $11.67 \pm 0.21^{\mathrm{a}}$ & $0.14 \pm 0.01^{\mathrm{a}}$ & $0.68 \pm 0.00^{\mathrm{b}}$ & $83.56 \pm 0.41^{\mathrm{a}}$ \\
FP25 & $30.30 \pm 1.32^{\mathrm{a}}$ & $11.5 \pm 0.40^{\mathrm{a}}$ & $0.20 \pm 0.01^{\mathrm{a}}$ & $0.70 \pm 0.01^{\mathrm{b}}$ & $82.84 \pm 0.49^{\mathrm{a}}$ \\
FP50 & $29.78 \pm 1.58^{\mathrm{a}}$ & $10.92 \pm 0.07^{\mathrm{a}}$ & $0.22 \pm 0.02^{\mathrm{a}}$ & $0.81 \pm 0.01^{\mathrm{a}}$ & $82.33 \pm 0.18^{\mathrm{a}}$ \\
FP75 & $30.21 \pm 2.04^{\mathrm{a}}$ & $10.96 \pm 0.34^{\mathrm{a}}$ & $0.24 \pm 0.05^{\mathrm{a}}$ & $0.80 \pm 0.02^{\mathrm{a}}$ & $80.51 \pm 0.54^{\mathrm{a}}$ \\
\hline
\end{tabular}

${ }^{1} \mathrm{FP0}$ (control sample without addition of orange byproducts dietary fiber), FP25 (addition of $25 \mathrm{~g} / \mathrm{kg}$ of orange byproducts dietary fiber), FP50 (addition of $50 \mathrm{~g} / \mathrm{kg}$ of orange byproducts dietary fiber), and FP75 (addition of $75 \mathrm{~g} / \mathrm{kg}$ of orange byproducts dietary fiber). ${ }^{2}$ Results are means of three determinations \pm standard deviation. Different letters in the same column are significantly different as determined by Tukey's test $(\mathrm{p} \leq 0.05) .{ }^{3}$ The amount of carbohydrates is discounted from the total fiber value. 
the highest content in orange byproducts fibers and is cited as more oxidation labile, i.e., small temperature changes are required to reduce these compounds rapidly. (Crizel et al., 2013; Fratianni et al., 2010; Rodriguez-Amaya, 2001).

Ajila et al. (2010) observed high yields of carotenoid content in macaroni enriched with mango peel powder. An increase of 18-fold was reported in the carotenoid level after pasta enrichment. However, the authors did not analyze the cooked pastas. The addition of $75 \mathrm{~g} / \mathrm{kg}$ mango peel powder resulted in $84 \pm 2 \mu \mathrm{g} / \mathrm{g}$ of carotenoid in the macaroni (Ajila et al., 2010 ), which is higher than the result observed in our study $(66.58 \pm 1.62 \mu \mathrm{g} / \mathrm{g})$. This difference can be related to the type and content of carotenoid found naturally in byproducts and to differences in the processing and fiber storage (RodriguezAmaya, 2001).

Phenolic compounds have been studied due to their diverse health benefits as antioxidants (Acosta-Estrada et al., 2014). Orange fiber byproducts are a good source of phenolic compounds and can be used as a functional ingredient in pasta (Crizel et al., 2013).

There was a significant increase in the total phenolic content in pasta enriched in $75 \mathrm{~g} / \mathrm{kg}$ of fiber $(1.68 \pm 0.15 \mathrm{mg} \mathrm{GAE} / \mathrm{g})$ when compared to control pasta $(1.19 \pm 0.05 \mathrm{mg}$ GAE/g). A similar polyphenolic content was obtained by Ovando-Martinez et al. (2009) with cooked spaghetti supplemented with $45 \mathrm{~g} / \mathrm{kg}$ of banana flour (1.68 mg GAE/g).

Table 2. Cooking characteristics of control and orange fiber-enriched pasta ${ }^{*}$.

\begin{tabular}{ccc}
\hline Sample $^{1}$ & Solid loss $(\%)^{2}$ & Weight increase $(\%)^{2}$ \\
\hline FP0 & $5.57 \pm 0.09^{\mathrm{c}}$ & $85.53 \pm 1.23^{\mathrm{a}}$ \\
FP25 & $5.67 \pm 0.14^{\mathrm{bc}}$ & $87.52 \pm 3.93^{\mathrm{a}}$ \\
FP50 & $7.98 \pm 0.65^{\mathrm{a}}$ & $88.14 \pm 1.02^{\mathrm{a}}$ \\
FP75 & $7.02 \pm 0.0^{\mathrm{ab}}$ & $88.19 \pm 3.87^{\mathrm{a}}$ \\
\hline
\end{tabular}

${ }^{1} \mathrm{FP0}$ (control sample, without addition of orange byproducts dietary fiber), FP25 (addition of $25 \mathrm{~g} / \mathrm{kg}$ of orange byproducts dietary fiber), FP50 (addition of $50 \mathrm{~g} / \mathrm{kg}$ of orange byproducts dietary fiber), and FP75 (addition of $75 \mathrm{~g} / \mathrm{kg}$ of orange byproducts dietary fiber). ${ }^{2}$ Results are means of three determinations \pm standard deviation. Different letters in the same column are significantly different as determined by Tukey's test $(\mathrm{p} \leq 0.05) .{ }^{*}$ cooking time: 4 minutes.
According to Hirawan et al. (2010), the total phenolic content is affected by pasta cooking due to high temperature-induced dissolution of these compounds in the cooking water. However, statistical analysis showed that all of the pasta samples supplemented with orange fiber did not have differences $(p>0.05)$ in the content of total phenolic compounds after cooking.

Boroski et al. (2011) observed lower content of phenolic compounds in pasta enriched with $100 \mathrm{~g} / \mathrm{kg}$ of carrot leaf (1.20 mg GAE/g) compared to the results reported in this study.

The results of the color parameters of sample pastas are presented in Table 4 . The incorporation of orange fiber did not affect the parameters of the original pasta color. The $L^{*}$ parameter of uncooked pastas was not significantly different at the different levels of fiber. The cooked pastas showed significantly lower values for the $L^{*}$ parameter when compared to uncooked pastas, indicating that the samples turned darker after cooking. The $a^{*}$ and $b^{*}$ parameters did not differ after the orange fiber addition and cooking, being the positive values of $a^{*}$ parameter related to the intensity of redness in the sample and the $b^{*}$ parameter related to the yellowness of samples.

The difference in color $(\Delta \mathrm{E})$ calculated by Equation 2 showed that the incorporation of orange fiber byproducts resulted in a loss of pasta color after cooking that was not significantly different $(p>0.05)$ compared to the control pasta (FP0). The $\Delta \mathrm{E}$ values for FP25, FP50 and FP75 were 18.66, 18.04 and 15.13, respectively, due to thermal degradation of carotenoid pigments in the pasta.

The results of fresh pasta acceptance attributes are evaluated in Table 5. It was found that the analyzed attributes of appearance, flavor and texture showed no significant difference $(p>0.05)$ between the standard sample (FP0) and the sample pasta enriched with $25 \mathrm{~g} / \mathrm{kg}$ orange fiber (FP25).

The addition of dietary orange fiber at $25 \mathrm{~g} / \mathrm{kg}$ and $50 \mathrm{~g} / \mathrm{kg}$ in pastas improved the pasta color according to the judges. The first quality parameter a customer can identify in food products is the color. It is the most important attribute used by the customer to evaluate the quality of a product and its probable taste without touching the product (Andrés-Bello et al., 2013).

Sensory evaluation showed that the pastas with increased levels of incorporation of orange fiber decreased the attribute

Table 3. Total polyphenol content, carotenoids and dietary fiber of pasta enriched with different levels of orange byproducts dietary fiber.

\begin{tabular}{|c|c|c|c|c|c|c|}
\hline \multicolumn{2}{|c|}{ Samples ${ }^{1}$} & \multirow{2}{*}{$\begin{array}{c}\begin{array}{c}\text { Total Polyphenol } \\
(\mathrm{mg} \mathrm{GAE} / \mathrm{g})^{2}\end{array} \\
1.19 \pm 0.05^{\mathrm{b}}\end{array}$} & \multirow{2}{*}{$\frac{\text { Carotenoid }(\mu \mathrm{g} / \mathrm{g})^{2}}{51.52 \pm 0.75^{\mathrm{b}}}$} & \multirow{2}{*}{$\frac{\operatorname{SDF}(\%)^{2}}{2.19 \pm 0.39^{\mathrm{a}}}$} & \multirow{2}{*}{$\frac{\operatorname{IDF}(\%)^{2}}{1.58 \pm 0.31^{\mathrm{c}}}$} & \multirow{2}{*}{$\frac{\operatorname{TDF}(\%)^{2}}{3.77 \pm 0.09^{\mathrm{c}}}$} \\
\hline FP0 & Uncooked & & & & & \\
\hline & Cooked & $1.15 \pm 0.09^{\mathrm{b}}$ & $7.67 \pm 0.54^{\mathrm{d}}$ & - & - & - \\
\hline \multirow[t]{2}{*}{ FP25 } & Uncooked & $1.37 \pm 0.17^{\mathrm{ab}}$ & $51.88 \pm 2.18^{\mathrm{b}}$ & $2.62 \pm 0.15^{\mathrm{a}}$ & $2.09 \pm 0.16^{b c}$ & $4.71 \pm 0.01^{\mathrm{c}}$ \\
\hline & Cooked & $1.42 \pm 0.04^{\mathrm{ab}}$ & $9.22 \pm 0.44^{\mathrm{d}}$ & - & - & - \\
\hline \multirow[t]{2}{*}{ FP50 } & Uncooked & $1.47 \pm 0.12^{\mathrm{ab}}$ & $64.79 \pm 2.89^{\mathrm{a}}$ & $2.39 \pm 0.47^{\mathrm{a}}$ & $3.35 \pm 0.34^{\mathrm{ab}}$ & $5,74 \pm 0.13^{b}$ \\
\hline & Cooked & $1.54 \pm 0.21^{\mathrm{ab}}$ & $14.81 \pm 1.55^{\mathrm{c}}$ & - & - & - \\
\hline \multirow[t]{2}{*}{ FP75 } & Uncooked & $1.68 \pm 0.15^{\mathrm{a}}$ & $66.58 \pm 1.62^{\mathrm{a}}$ & $3.14 \pm 0.59^{\mathrm{a}}$ & $4.36 \pm 0.46^{\mathrm{a}}$ & $7.50 \pm 0.13^{\mathrm{a}}$ \\
\hline & Cooked & $1.65 \pm 0.12^{\mathrm{a}}$ & $15.17 \pm 0.31^{\mathrm{c}}$ & - & - & - \\
\hline
\end{tabular}

${ }^{1} \mathrm{FP} 0$ (control sample, without addition of orange byproducts dietary fiber), FP25 (addition of $25 \mathrm{~g} / \mathrm{kg}$ of orange byproducts dietary fiber), FP50 (addition of $50 \mathrm{~g} / \mathrm{kg}$ of orange byproducts dietary fiber), and FP75 (addition of $75 \mathrm{~g} / \mathrm{kg}$ of orange byproducts dietary fiber). TDF (Total dietary fiber); IDF (Insoluble dietary fiber); SDF (Soluble dietary fiber). ${ }^{2}$ Results are means of three determinations \pm standard deviation. Different letters in the same column are significantly different as determined by Tukey's test ( $\mathrm{p} \leq 0.05)$. 
Table 4. Color parameters of uncooked and cooked pastas by the CIELAB method.

\begin{tabular}{|c|c|c|c|c|c|}
\hline \multicolumn{2}{|c|}{ Samples $^{1}$} & \multirow{2}{*}{$\frac{L^{\star 2}}{79.71 \pm 6.78^{\mathrm{a}}}$} & \multirow{2}{*}{$\frac{a^{\star 2}}{0.39 \pm 0.04^{\mathrm{a}}}$} & \multirow{2}{*}{$\frac{b^{\star 2}}{15.04 \pm 3.73^{\mathrm{a}}}$} & \multirow{2}{*}{$\frac{\Delta \mathrm{E}^{2}}{15.57 \pm 3.68}$} \\
\hline FP0 & Uncooked & & & & \\
\hline & Cooked & $64.41 \pm 3.46^{\mathrm{bc}}$ & $-0.06 \pm 0.01^{\mathrm{a}}$ & $16.80 \pm 0.10^{\mathrm{a}}$ & \\
\hline \multirow[t]{2}{*}{ FP25 } & Uncooked & $79.98 \pm 3.64^{\mathrm{a}}$ & $1.37 \pm 0.78^{\mathrm{a}}$ & $15.52 \pm 1.55^{\mathrm{a}}$ & $18.66 \pm 1.87^{\circ}$ \\
\hline & Cooked & $62.45 \pm 2.26^{b c}$ & $0.47 \pm 0.20^{\mathrm{a}}$ & $21.75 \pm 0.32^{\mathrm{a}}$ & \\
\hline \multirow[t]{2}{*}{ FP50 } & Uncooked & $81.09 \pm 1.94^{\mathrm{a}}$ & $0.35 \pm 0.01^{\mathrm{a}}$ & $16.67 \pm 0.06^{\mathrm{a}}$ & $18.04 \pm 5.28^{\circ}$ \\
\hline & Cooked & $63.92 \pm 2.63^{b c}$ & $-0.17 \pm 1.32^{\mathrm{a}}$ & $21.93 \pm 3.28^{\mathrm{a}}$ & \\
\hline \multirow[t]{2}{*}{ FP75 } & Uncooked & $70.73 \pm 0.54^{\mathrm{ab}}$ & $1.59 \pm 0.01^{\mathrm{a}}$ & $20.09 \pm 1.42^{\mathrm{a}}$ & $15.13 \pm 0.31^{\circ}$ \\
\hline & Cooked & $55.74 \pm 0.76^{c}$ & $0.52 \pm 0.05^{\mathrm{a}}$ & $18.42 \pm 1.99^{\mathrm{a}}$ & \\
\hline
\end{tabular}

${ }^{1} \mathrm{FP0}$ (control sample, without addition of orange byproducts dietary fiber), FP25 (addition of $25 \mathrm{~g} / \mathrm{kg}$ of orange byproducts dietary fiber), FP50 (addition of $50 \mathrm{~g} / \mathrm{kg}$ of orange byproducts dietary fiber), FP75 (addition of $75 \mathrm{~g} / \mathrm{kg}$ of orange byproducts dietary fiber). ${ }^{2}$ Results are means of three determinations \pm standard deviation. Different letters in the same column are significantly different as determined by Tukey's test $(\mathrm{p} \leq 0.05)$.

Table 5. Influence of orange fiber on the sensory acceptability of macaroni.

\begin{tabular}{cccccccc}
\hline Sample $^{1}$ & Appearance $^{2}$ & Color $^{2}$ & Flavor $^{2}$ & Texture $^{2}$ & Taste $^{2}$ & Aftertaste $^{2}$ & Overall acceptability $^{2}$ \\
\hline FP0 & $6.0 \pm 1.8^{\mathrm{ab}}$ & $5.9 \pm 1.8^{\mathrm{b}}$ & $6.8 \pm 1.2^{\mathrm{a}}$ & $6.5 \pm 1.8^{\mathrm{a}}$ & $7.1 \pm 1.2^{\mathrm{a}}$ & $6.9 \pm 1.4^{\mathrm{a}}$ & $6.9 \pm 1.1^{\mathrm{a}}$ \\
FP25 & $6.7 \pm 1.6^{\mathrm{a}}$ & $6.8 \pm 1.4^{\mathrm{a}}$ & $6.7 \pm 1.4^{\mathrm{a}}$ & $6.6 \pm 1.7^{\mathrm{a}}$ & $6.6 \pm 1.5^{\mathrm{a}}$ & $6.4 \pm 1.6^{\mathrm{a}}$ & $6.8 \pm 1.3^{\mathrm{a}}$ \\
FP50 & $6.7 \pm 1.4^{\mathrm{a}}$ & $7.0 \pm 1.3^{\mathrm{a}}$ & $7.0 \pm 1.3^{\mathrm{a}}$ & $6.4 \pm 1.4^{\mathrm{a}}$ & $5.1 \pm 1.8^{\mathrm{b}}$ & $4.6 \pm 2.0^{\mathrm{b}}$ & $5.8 \pm 1.6^{\mathrm{b}}$ \\
FP75 & $5.3 \pm 1.8^{\mathrm{b}}$ & $5.1 \pm 1.8^{\mathrm{b}}$ & $6.3 \pm 1.6^{\mathrm{a}}$ & $6.0 \pm 1.6^{\mathrm{a}}$ & $4.7 \pm 2.0^{\mathrm{b}}$ & $3.8 \pm 1.9^{\mathrm{b}}$ & $4.6 \pm 1.8^{\mathrm{c}}$ \\
\hline
\end{tabular}

${ }^{1} \mathrm{FP0}$ (control sample, without addition of orange byproducts dietary fiber), FP25 (addition of $25 \mathrm{~g} / \mathrm{kg}$ of orange byproducts dietary fiber), FP50 (addition of $50 \mathrm{~g} / \mathrm{kg}$ of orange byproducts dietary fiber), and FP75 (addition of $75 \mathrm{~g} / \mathrm{kg}$ of orange byproducts dietary fiber). ${ }^{2} \mathrm{Mean}$ values \pm standard deviation. Values with different letters in the same columns are significantly different as determined by Tukey's test $(p \leq 0.05)$.

acceptance of taste, aftertaste, and overall acceptance. While the FP75 sample presented averages of less than 4 (dislike slightly) for the aftertaste attribute, the low scores for these attributes can be associated with the presence of bitter taste due to orange seed and peel being used in the preparation of the fiber. Flavonoids in citrus fruit include flavonoids (naringin), flavones (nobiletin), and flavonols (quercetin). The flavones (tangeretin and nobiletin) are concentrated in the peel of unripe fruit and are the constituents of bitter citrus oils. Naringin is another very bitter compost found at the highest concentration in the pulp of immature fruit (Drewnowski \& Gomez-Carneros, 2000). These flavonoids indicate the need for a pretreatment of raw material to reduce the compounds responsible for bitterness (characteristic of orange fibers). According to Crizel et al. (2014), pretreating the orange peel was an effective approach to decrease the bitter taste when the fiber (at $10 \mathrm{~g} / \mathrm{kg}$ ) was used as a fat replacement in lemon ice cream and did not change the product sensory properties.

The sensory results presented in this work were similar to those obtained by Ajila et al. (2010) with pasta enriched with mango peel powder. The sensory attributes of color and texture were not affected by the increase in the concentration of mango powder, but the judges rated these with the lowest means for attributes of flavor and overall acceptability. In the same way, Sant'Anna et al. (2014) showed that fettuccini pasta with the incorporation of $25 \mathrm{~g} / \mathrm{kg}, 50 \mathrm{~g} / \mathrm{kg}$ and $75 \mathrm{~g} / \mathrm{kg}$ of grape marc powder resulted in lower acceptance.

The fresh pasta supplemented with $25 \mathrm{~g} / \mathrm{kg}$ and $50 \mathrm{~g} / \mathrm{kg}$ of orange fiber obtained a percentage of overall acceptability of $76 \%$ and $64 \%$, respectively, indicating that although the judges perceived aftertaste in these pastas, the product has market potential. The market potential can be evidenced by the results of physico-chemical and functional analysis, since in both formulations the addition of fiber does not negatively affect the samples cooking characteristics and color, and provided an increase in the value of total fibers and a significant increase in carotenoid content of the pastas supplemented with $50 \mathrm{~g} / \mathrm{kg}$ of orange fiber.

It is interesting to highlight that the judges had no previous knowledge of the samples and their nutritional characteristics. Knowledge of these characteristics may positively affect the outcome of attribute acceptance given that healthier products that incorporate additional nutrients are being increasingly consumed by the population and, over the past few years, have changed Brazilian eating habits.

\section{Conclusion}

The incorporation of orange fiber byproducts in fresh pasta is an attractive alternative because they increased both the antioxidant capacity and fiber content of the fettuccini fresh pastas without altering their quality properties. Pasta supplemented with $25 \mathrm{~g} / \mathrm{kg}$ of orange fiber can be considered a "source fiber" product, and the sensory analysis of its attributes suggests that this formulation has a great potential industrial application. However, a pretreatment of raw material should be realized for reduce the compounds responsible for bitterness (characteristic of orange fibers).

\section{References}

Acosta-Estrada, B. A., Gutiérrez-Uribe, J. A., \& Serna-Saldívar, S. O. (2014). Bound phenolics in foods, a review. Food Chemistry, 152, 46-55. http://dx.doi.org/10.1016/j.foodchem.2013.11.093. PMid:24444905.

Ajila, C. M., Aalami, M., Leelavathi, K., \& Rao, U. J. S. P. (2010). Mango Peel powder: A potential source of antioxidant and dietary fiber in 
macaroni preparations. Innovative Food Science \& Emerging Technologies, 11(1), 219-224. http://dx.doi.org/10.1016/j.ifset.2009.10.004.

American Association of Cereal Chemists - AACC. (2000). Approved methods of the American Association of Cereal Chemists (10th ed). Saint Paul: AACC International.

Andrés-Bello, A., Barreto-Palacios, V., García-Segovia, P., Mir-Bel, J., \& Martínez-Monzo, J. (2013). Effect of $\mathrm{pH}$ on color and texture of food products. Food Engineering Reviews, 5(3), 158-170. http:// dx.doi.org/10.1007/s12393-013-9067-2.

Associação Brasileira das Indústrias de Massas Alimentícias Pão \& Bolo Industrializado - ABIMA. (2014, May 22). São Paulo. Retrieved from http:// http://www.abima.com.br

Association of Official Analytical Chemist - AOAC. (1990). Official methods of analysis (15th ed., Vol. 2). Arlington.

Bergman, C., Gualberto, D., \& Weber, C. (1994). Development of hightemperature dried soft wheat macaroni supplemented with cowpea (Vigna unguiculata L. Walp). Cooking quality, colour and sensory evaluation. Cereal Chemistry, 71(6), 523-527.

Boroski, M., de Aguiar, A. C., Boeing, J. S., Rotta, E. M., Wibby, C. L., Bonafé, E. G., de Souza, N. E., \& Visentainer, J. V. (2011). Enhancement of pasta antioxidant activity with oregano and carrot leaf. Food Chemistry, 125(2), 696-700. http://dx.doi.org/10.1016/j. foodchem.2010.09.068.

Brasil. Agência Nacional de Vigilância Sanitária - ANVISA. (1998, January 16). Portaria $n^{\circ} 27$, de 13 de janeiro de 1998. Aprova o Regulamento Técnico referente à Informação Nutricional Complementar (declarações relacionadas ao conteúdo de nutrientes). Diário Oficial da União. Retrieved from http://www.anvisa.gov.br/e-legis

Crizel, T. M., Araujo, R. R., Rios, A. O., Rech, R., \& Flôres, S. H. (2014). Orange fiber as a novel fat replacer in lemon ice cream. Food Science and Technology, 34(2), 332-340. http://dx.doi.org/10.1590/fst.2014.0057.

Crizel, T. M., Jablonski, A., Rios, A. O., Rech, R., \& Flôres, S. H. (2013). Dietary fiber from orange byproducts as a potential fat replacer. $L W T$ - Food Science and Technology, 53, 9-14. http://dx.doi.org/10.1016/j. lwt.2013.02.002.

Drewnowski, A., \& Gomez-Carneros, C. (2000). Bitter taste, phytonutrients, and the consumer: a review. The American Journal of Clinical Nutrition, 72(6), 1424-1435. PMid:11101467.

Dutcosky, S. D. (1996). Análise sensorial de alimentos. Curitiba: Champagnat. $123 \mathrm{p}$.

Elleuch, M., Bedigian, D., Roiseux, O., Besbes, S., Blecker, C., \& Attia, H. (2011). Dietary fibre and fibre-rich by-products of food processing: Characterisation, technological functionality and commercial applications: A review. Food Chemistry, 124(2), 411-421. http:// dx.doi.org/10.1016/j.foodchem.2010.06.077.

Fares, C., \& Menga, V. (2012). Effects of toasting on the carbohydrate profile and antioxidant properties of chickpea (Cicer arietinum L.) flour added to durum wheat pasta. Food Chemistry, 131(4), 11401148. http://dx.doi.org/10.1016/j.foodchem.2011.09.080.

Fratianni, A., Cinquanta, L., \& Panfili, G. (2010). Degradation of carotenoids in orange juice during microwave heating. LWT - Food Science and Technology, 43, 867-871.

Granito, M., Torres, A., \& Guerra, M. (2003). Desarrollo y evaluación de una pasta a base de trigo, maíz, yuca y frijol. Interciencia, 28, 372-379.

Grigelmo-Miguel, N., \& Martín-Belloso, O. (1999). Characterization of dietary fiber from orange juice extraction. Food Research International, 31, 335-361.

Hirawan, R., Ser, W. Y., Arntfield, S. D., \& Beta, T. (2010). Antioxidant properties of commercial, regular- and whole-wheat spaghetti.
Food Chemistry, 119(1), 258-264. http://dx.doi.org/10.1016/j. foodchem.2009.06.022.

Hoseney, C. (1999). Principles of cereal science and technology (pp. 269274). St. Paul: American Association of Cereal Chemists.

Lima, B. N. B., Lima, F. F., Tavares, M. I. B., Costa, A. M. M., \& Pierucci, A. P. T. R. (2014). Determination of the centesimal composition and characterization of flours from fruit seeds. Food Chemistry, 151, 293-299. http://dx.doi.org/10.1016/j.foodchem.2013.11.036. PMid:24423535.

Lichtenthaler, H. K. (1987). Chlorophylls and carotenoids: Pigments of photosynthetic biomembranes. Methods in Enzymology, 148, 350 383. http://dx.doi.org/10.1016/0076-6879(87)48036-1.

Meilgaard, M., Civille, G. V., \& Carr, B. T. (2007). Sensory evaluation techniques (4th ed.). Boca Raton: CRC Press.

Minolta. (1993). Precise color communication: color control form feeling to instrumentation. Osaka: Minolta Camera.

O’Shea, N., Arendt, E. K., \& Gallagher, E. (2012). Dietary fibre and phytochemical characteristics of fruit and vegetable by-products and their recent applications as novel ingredients in food products. Innovative Food Science \& Emerging Technologies, 16, 1-10. http:// dx.doi.org/10.1016/j.ifset.2012.06.002.

Ovando-Martinez, M., Sáyago-Ayerdi, S., Agama-Acevedo, E., Goñi, I., \& Bello-Pérez, L. A. (2009). Unripe banana flour as an ingredient to increase the indigestible carbohydrates of pasta. Food Chemistry, 113(1), 121-126. http://dx.doi.org/10.1016/j.foodchem.2008.07.035.

Padalino, L., Mastromatteo, M., Lecce, L., Spinelli, S., Conto, F., \& Del Nobile, M. A. (2014). Chemical composition, sensory and cooking quality evaluation of durum wheat spaghetti enriched with pea flour. International Journal of Food Science \& Technology, 49(6), 1544-1556. http://dx.doi.org/10.1111/ijfs. 12453.

Rodriguez-Amaya, D. B. (2001). A guide to carotenoid analysis in foods. Washington: International Life Sciences Institute Press.

Romero-Lopez, M. R., Osorio-Diaz, P., Bello-Perez, L. A., Tovar, J., \& Bernardino-Nicanor, A. (2011). Fiber concentrate from orange (Citrus sinensis L.) bagase: characterization and application as bakery product ingredient. International Journal of Molecular Sciences, 12(4), 2174-2186. http://dx.doi.org/10.3390/ijms12042174. PMid:21731434.

Sant'Anna, V., Christiano, F. D. P., Marczak, L. D. F., Tessaro, I. C., \& Thys, R. C. S. (2014). The effect of the incorporation of grape marc powder in fettuccini pasta properties. LWT - Food Science and Technology, 58, 497-501.

Schieber, C., Stintzing, F. C., \& Carle, R. (2001). By-products of plant food processing as a source of functional compounds: recent developments. Trends in Food Science \& Technology, 12(11), 401413. http://dx.doi.org/10.1016/S0924-2244(02)00012-2.

Singleton, V. L., \& Rossi, J. A. (1965). Colorimetry of total phenolics with phosphomolybdic-phosphotungstic acid reagents. American Journal of Enology and Viticulture, 16, 144-158.

Torres, A., Frias, J., Granito, M., \& Vidal-Valverde, C. (2007). Germinated Cajanus cajan seeds as ingredients in pasta products: Chemical, biological and sensory evaluation. Food Chemistry, 101(1), 202-211. http://dx.doi.org/10.1016/j.foodchem.2006.01.018.

Tudorica, C. M., Kuri, V., \& Brennan, C. S. (2002). Nutritional and physicochemical characteristics of dietary fiber enriched pasta. Journal of Agricultural and Food Chemistry, 50(2), 347-356. http:// dx.doi.org/10.1021/jf0106953. PMid:11782206. 